\title{
PENGARUH KUALITAS PELAYANAN, LOKASI, HARGA DAN DIGITAL MARKETING TERHADAP LOYALITAS KONSUMEN DI GRAND WAHID HOTEL SALATIGA
}

\author{
Yuni Maxi Putri ${ }^{1}$, Hardi Utomo ${ }^{2}$, Fudji Sri Mar'ati ${ }^{3}$ \\ Mahasiswa Program Studi Manajemen, STIE AMA Salatiga \\ ${ }^{1)}$ yunimaxiputri@gmail.com \\ Dosen Program Studi Manajemen, STIE AMA Salatiga \\ 2) utomohardi@yahoo.com \\ Dosen Program Studi Akuntansi, STIE AMA Salatiga \\ 3) fudjism@gmail.com
}

\begin{abstract}
ABSTRAK
Penelitian ini dilatar belakangi oleh tingkat persaingan hotel di Salatiga yang cukup tinggi yang tidak diimbangi dengan peningkatan jumlah wisatawan dan minimnya destinasi wisata di Salatiga.Tujuan Penelitian ini adalah untuk mengetahui: pengaruh kualitas pelayanan, lokasi, harga, dan digital marketing secara parsial maupun simultan terhadap loyalitas konsumen di Grand Wahid Hotel Salatiga. Tipe penelitian yang digunakan adalah explanatory, jenis data kualitatif dan menggunakan data primer yang berupa kuesioner. Metode analisis yang digunakan yaitu analisis regresi linier berganda, uji $t$, uji $f$, dan koefisien determinasi. Dari hasil analisis regresi linier berganda menunjukan variabel independen berpengaruh terhadap variabel dependen. Hasil uji parsial kualitas pelayanan dan lokasi tidak berpengaruh signifikan terhadap loyalitas konsumen, karena t hitung lebih kecil dari ttabel, artinya jika kualitas pelayanan dan lokasi ditingkatkan maka tidak berpengaruh signifikan pada loyalitas konsumen. Sedangkan hasil uji parsial harga dan digital marketing thitung lebih besar dari ttabel, yang artinya jika harga dan digital marketing ditingkatkan maka loyalitas konsumen akan meningkat pula. Hasil uji simultan dari semua variabel independen fhitung lebih besar dariftabel, yang berarti semua variabel indepent berpengaruh signifikan terhadap loyalitas konsumen juga akan meningkat pula.
\end{abstract}

Kata kunci : kualitas pelayanan, lokasi, harga, digital marketing, loyalitas konsumen.

\section{PENDAHULUAN}

Salah satu tujuan penting dari kegiatan pemasaran adalah suatu perusahaan memiliki konsumen yang loyal. Loyalitas konsumen menurut Gremler dan Brown (dalam Warnadi \& Triyono, 2019) yaitu, loyalitas konsumen adalah konsumen yang tidak hanya melakukan satu kali transaksi, tetapi berkomitmen positif terhadap perusahaan produk atau jasa.Menurut Engle, Blackwell, Miniardi (dalam Warnadi \& Triyono, 2019) loyalitas konsumen merupakan pola perilaku konsumen dalam melakukan pengulangan pembelian, keyakinan yang tinggi terhadap pilihan dengan pencarian informasi yang jelas.

Menurut Kotler dan Amstrong (dalam Nurulaili \& Wijayanto, 2013) pemasaran merupakan suatu proses sosial dan manajerial di mana individu maupun kelompok memperoleh kebutuhan dan keinginan mereka terhadap sesuatu yang bernilai satu sama 
lain. Dalam implementasinya, pemasaran memberikan informasi produk terhadap konsumen. Pernyataan tersebut merupakan bagian dari strategi pemasaran.

Industri perhotelan merupakan industri dalam bidang jasa yang memadukan antara produk dan pelayanan. Untuk produk, hotel menjual kamar, makanan, fasilitas kepada konsumen dengan didukung desain bangunan, interior, eksterior dan nuansa khas yang diciptakan hotel. Sedangkan untuk pelayanan yang dijual adalah hospitality atau keramah-tamahan dan keterampilan serta sikap karyawan dalam melayani konsumen. Hal ini sejalan dengan pengertian hotel menurut SK Menparpostel dalam buku Pengantar Statistik Kesehatan (Devi, 2018) merupakan suatu jenis akomodasi yang memanfaatkan sebagian atau seluruh bangunan untuk menyediakan jasa pelayanan penginapan, makanan dan minuman, serta jasa lain bagi masyarakat umum yang dikelola secara komersial dan memenuhi ketentuan persyaratan yang ditetapkan pemerintah.

Penjualan hotel merupakan salah satu implementasi dari pemasaran. Usaha penjualan hotel akan memberikan pengaruh kepada occupancy hotel dan operasional hotel. Dari sekian banyak faktor yang dapat memengaruhi, industri pariwisata merupakan aspek penting yang memberikan pengaruh besar terhadap penjualan hotel. Untuk itu, diperlukan upaya salah satunya melalui penerapan pelayanan prima. Hal ini sejalan dengan pendapat (Sanaubar et al., 2017) yang mengatakan bahwa hotel merupakan salah satu sarana yang dapat digunakan untuk menunjang dan memaksimalkan pelayanan bagi para wisatawan sebagai bentuk dukungan terhadap industri pariwisata. Salatiga termasuk dalam kategori kota kecil dengan jumlah destinasi wisata yang sedikit, namun Salatiga termasuk dalam kota transit yang masih sering disinggahi pengunjung.

Penelitian ini dilatarbelakangi oleh tingkat persaingan hotel di Salatiga yang cukup tinggi yang tidak diimbangi dengan peningkatan jumlah wisatawan dan minimnya destinasi wisata di Salatiga. Hal ini tentu saja akan berpengaruh terhadap jumlah pengunjung yang menginap di hotel. Penyedia layanan jasa perhotelan harus menyiapkan strategi terbaik untuk menarik konsumen, salah satunya Grand Wahid Hotel sebagai penyedia layanan jasa perhotelan di Salatiga. Grand Wahid Hotel Salatiga merupakan hotel berbintang empat berlokasi di Jalan Jenderal Sudirman No. 2 Salatiga yang memiliki 103 kamar dengan berbagai tipe mulai dari superior room, deluxe room, executive room, suite room dan president suite room dengan fasilitas yang berbeda sesuai masing-masing tipe atau kelasnya. Grand Wahid Hotel memiliki lima ruang meeting yang dapat digunakan untuk berbagai acara. Selain fasilitas menginap dan pertemuan, Grand Wahid juga memiliki fasilitas umum lain seperti restaurant, kolam renang, fitness center dan karaoke. Grand Wahid Hotel Salatiga seharusnya berupaya untuk mengedepankan fasilitas sebagai implementasi dari pemasaran.Hal ini sejalan dengan pengertian fasilitas menurut Youti (dalam Emmywati, 2016) dimana "Fasilitas adalah segala sesuatu baik benda maupun jasa yang menyertai pelayanan yang diberikan oleh perusahaan baik perusahaan jasa, dagang maupun perusahaan industri." Faktor lain adalah lokasi. Pemilihan lokasi yang strategis sangat penting dalam menarik konsumen, karena pada umumnya konsumen akan mencari lokasi yang mudah diakses. Hal ini sejalan dengan pengertian lokasi menurut (Sibarani et al., 2019) lokasi dalam hubungannya dengan pemasaran adalah tempat yang khusus dan tertata unik, dimana tempat tersebut digunakan untuk berbelanja.

Berdasarkan hasil survey, untuk memaksimalkan pemasaran, Grand Wahid sudah menggunakan sistem pemasaran digital kreatif yang memiliki peluang besar dalam menarik konsumen dan memberikan informasi secara jelas dan menarik mengenai produk dan spesifikasinya. Pemasaran digital atau digital marketing merupakan pertemuan antara 
penjual dan pembeli yang tidak dilakukan secara nyata namun dapat melakukan transaksi dan segala mendapatkan segala macam informasi produk melalui dunia maya (Afrilia \& Ascharisa Mettasatya, 2018).

Tujuan dari penelitian ini adalah untuk mempelajari pengaruh empat variable pemasaran dalam mempengaruhi loyalitas konsumen di Grand Wahid Hotel Salatiga.Menurut Hasan (dalam Putri, 2017) loyalitas merupakan suatu kondisi psikologis dimana konsumen mulai menumbuhkan keyakinan akan suatu produk, menilai suka atau tidak suka terhadap suatu produk dan memutuskan untuk membeli suatu produk. Loyalitas konsumen sangat terkait dengan merek produk. Beberapa kemungkinan yang terjadi oleh konsumen yaitu memutuskan untuk tetap menggunakan, beralih atau meninggalkan produk/jasa atau mengajukan perubahan citra baru terhadap produk/jasa. Oleh karena itu, perusahaan harus tetap berusaha mempertahankan kualitas produk atau jasa agar senantiasa diminati oleh konsumen. Menurut Griffin (dalam Nurulaili \& Wijayanto, 2013) ciri-ciri dari konsumen yang loyalitas yaitu, melakukan pembelian ulang secara teratur, membeli antar lini produk atau jasa mereferensikan kepada orang lain, menunjukkan kekebalan dari daya tarik produk sejenis dari orang lain.

Berdasarkan penjelasan di atas, diharapkan Grand Wahid Hotel Salatiga dapat terus memperbaiki aspek-aspek tersebut untuk meningkatkan kenyamanankonsumen sehingga konsumen tidak beralih produk atau jasa dan tetap setia dengan perusahaan. Ketika konsumen memiliki loyalalitas, maka hal ini akan membantu keberhasilan Grand Wahid Hotel dan mampu memberikan profit yang lebih baik. Adapun data penelitian yang diambil berdasarkan occupancy hotel selama bulan Desember 2019 sampai dengan Februari 2020. Berdasarkan latar belakang penelitian yang telah dikemukakan di atas, maka peneliti bermaksud mengadakan penelitian untuk mengetahui pengaruh kualitas pelayanan, lokasi, harga dan digital marketing terhadap loyalitas konsumen di Grand Wahid Hotel Salatiga.

\section{LANDASAN TEORI DAN PENGEMBANGAN HIPOTESIS}

\section{Manajemen Pemasaran}

Menurut (Shinta, 2011) manajemen pemasaran merupakan rangkaian usaha mulai dari perencanaan dan pengimplementasian termasuk diantaranya mengorganisasi, mengarahkan dan mengkoordinir serta melakukan pengawasan dan pengendalian terhadap kegiatan pemasaran suatu organisasi agar dapat mencapai tujuan pemasaran secara efektif dan efisien. Manajemen pemasaran merupakan suatu proses dari awal perencanaan hingga berakhir pada evaluasi suatu kegiatan pemasaran.

Menurut (Suprapto \& Azizi, 2020) manajemen pemasaran adalah rangkaian kegiatan perencanaan, pengarahan dan pengawasan pemasaran yang mencakup kegiatan penarikan, pemilihan, penarikan rute, perlengkapan, pembayaran dan motivasi terhadap tenaga penjualan.

Adapun fungsi manajemen pemasaran menurut (Sudarsono, 2020)yaitu melakukan analisis untuk mengetahui pasar dan wilayah pemasaran, sehingga pemasar dapat melihat peluang sejauh mana produk atau jasa memiliki kesempatan serta analisis untuk mengetahui hambatan-hambatan yang mungkin terjadi. Proses pemasaran terbagi menjadi tiga kegiatan diantaranya :

1) Mendapatkan pelanggan baru (acquire)

2) Meningkatkan hubungan dengan pelanggan yang sudah ada (enhance)

3) Mempertahankan pelanggan yang sudah ada 
Kegiatan pemasaran terfokus pada kebutuhan pembeli, selalu mengutamakan kepuasan konsumen melalui produk atau jasa yang dijual. Kesuksesan dalam pemasaran dapat dilihat apabila suatu perusahaan mampu melakukan penjualan sesuai atau bahkan melebihi target yang ditentukan oleh suatu perusahaan.

\section{Loyalitas Konsumen}

Pengertian loyalitas konsumen menurut Supriyadi Setiawan (Setiawan, 2011) yaitu, loyalitas merupakan suatu istilah kuno yang secara tradisional digunakan untuk menggambarkan suatu kesetiaan, pengabdian terhadap negara, cita-cita dan lainnya. Sedangkan dalam konteks bisnis, loyalitas digunakan untuk menggambarkan kesetiaan dan kesediaan konsumen untuk terus berlangganan pada perusahaan dalam jangka panjang. Hal-hal tersebut dapat dilihat dari ciri-ciri sebagai berikut diantaranya membeli dan menggunakan barang secara berulang, memberikan dukungan positif terhadap produk perusahaan, merekomendasikan produk perusahaan terhadap kolega dan memiliki komitmen terhadap perusahaan dalam artian tidak mudah terbujuk atau tergoda dengan produk sejenis dari perusahaan lain.

Berdasarkan beberapa penelitian diatas dapat disimpulkan jika loyalitas konsumen merupakan suatu respon positif terhadap perusahaan ketika konsumen mendapatkan pelayanan yang baik. Loyalitas konsumen menjadi unsur tolok ukur keberhasilan pemasaran dan kualitas produk atau jasa. Konsumen yang loyal akan memberikan komitmen positif dan sikap positif terhadap produk dan perusahaan, tidak mudah berpindah kerjasama kepada perusahaan lain dan tidak ragu merokemendasikan produk atau jasa kepada kolega.Untuk mendapatkan loyalitas dari konsumen, perusahaan peru melakukan hubungan pelanggan dengan istilah CRM (Customer Relationship Management). CRM dalam (Sudarsono, 2020) merupakan pendekatan strategi dengan menciptakan, mengembangkan dan mewujudkan hubungan yang saling menguntungkan dengan tujuan jangka panjang.

Ada beberapa aspek produk atau jasa yang harus diperhatikan menurut perspektif relationship quality dalam (Tjiptono, 2014)dimana loyalitas pelanggan berkembang dari relasi pertemanan/pembelian biasa menjadi kemitraan berkomitmen dengan merek atau penyedia jasa spesifik. Bentuk hubungan antara pelanggan dengan produk/jasa dikategorikan dalam enam kategori, diantaranya :

1) Personal identity, suatu merek menggambarkan konsumen yang memakainya yang dapat mendukung personal branding atau citra seseorang.

2) Interdependence, suatu merek menggambarkan kehidupan konsumen sehari-hari.

3) Nostalgia, keterikatan konsumen dengan suatu merek dikarenakan koneksi masa lalu contohnya kenangan masa kecil, dan sebagainya.

4) Passion, suatu merek mampu menumbuhkan rasa cinta dan kekaguman yang mendalam dihati konsumen.

5) Commitment, suatu loyalitas atau kesetiaan konsumen terhadap merek dalam kondisi apapun.

6) Intimacy, suatu merek dipandang sebagai mitra oleh konsumen.

\section{Kualitas Pelayanan}

Menurut Tjiptono dalam buku Perspektif Manajemen \& Pemasaran Kontemporer (Tjiptono, 2000) konsep kualitas pelayanan selalu mengalami perkembangan dan tahapan. Dimulai dari era craftmanship, dimana individu diharuskan terampil dalam mengerjakan semua tugas yang dibutuhkan. Selanjutnya, ada tindakan lanjutan berupa 
pendekatan after the fact, yaitu evaluasi setelah terdapat kesalahan. Hal ini mendorong dibentuknya TQM (Total Quality Manajemen ). TQM merupakan suatu pendekatan dalam menjalankan bisnis atau usaha yang berupaya memaksimalkan daya saing melalui penyempurnaan atas produk, jasa, sumber daya manusia dan proses lingkungan. Adapun dimensi kualitas menurut TQM harus memerhatikan lima elemen yaitu kehandalan (reliability), jaminan (assurance), bukti fisik (tangible), empati (emphaty), daya tanggap (responsiveness).Berikut masing-masing uraian mengenai lima elemen kualitas :

1) Reliabilitas (Reliability), yaitu suatu kemampuan untuk memberikan pelayanan dengan cepat, akurat dan memuaskan konsumen.

2) Jaminan (Assurance), yaitu hal-hal yang mencakup pengetahuan, kompetensi, sikap dan kesopanan, karakter staff yang dapat dipercaya, aman, meyakinkan dan tidak ragu-ragu.

3) Bukti fisik (Tangible), yaitu mencakup fasilitas, sarana dan prasarana, pegawai dan sarana komunikasi yang memadai.

4) Empati (Emphaty), yaitu kemudahan dalam menjalin relasi, komunikasi yang baik, perhatian serta kepedulian dan pemahaman atas kebutuhan konsumen.

5) Daya tanggap (Responsiveness), yaitu kehandalan dan keinginan staff untuk membantu memenuhi kebutuhan konsumen dan memberikan peayanan dengan tanggap.

\section{Lokasi}

Menurut Tjiptono (Tjiptono, 2014) lokasi adalah tempat perusahaan beroperasi atau tempat perusahaan melakukan kegiatan untuk menghasilkan barang dan jasa yang mementingkan segi ekonomi. Lokasi juga merupakan satu aspek penting dalam bauran pemasaran jasa. Keputusan pemilihan lokasi merupakan keputusan yang penting bagi kesuksesan suatu usaha dengan memperhatikan beberapa hal berikut diantaranya:

1) Keterjangkauan lokasi / aksesbilitas jasa dengan konsumen

2) Visibilitas atau lokasi yang dapat dilihat dengan jarak pandang normal

3) Kepadatan lalu lintas

4) Tempat parkir yang luas

5) Ekspansi, perluasan bangunan

6) Persaingan

\section{Harga}

Menurut Fandy Tjiptono (Tjiptono, 2014) harga merupakan satu-satunya unsur bauran pemasaran yang memberikan pemasukan bagi perusahaan. Pengambilan keputusan penetapan harga merupakan suatu keputusan kritis yang menunjang keberhasilan organisasi. Dalam konteks pemasaran jasa, istilah harga dapat diartikan sebagai sejumlah uang baik satuan moneter atau non moneter yang memiliki utilitas atau kegunaan tertentu yang dapat dipergunakan untuk mendapatkan suatu jasa. Adapun beberapa faktor yang mempengaruhi dalam penetapaan harga jasa diantaranya permintaan pasar, aksi dan reaksi pesaing, biaya dan konsekuensi profitabilitas dan kebijakan lini produk.

Berdasarkan pemaparan diatas, dapat kita pahami jika harga memiliki peranan yang sangat penting terhadap pemasaran. Harga juga bersifat fleksibel, artinya dapat dengan mudah berubah menyesuaikan keadaan. Konsumen akan merasa puas ketika produk atau jasa yang diterima kualitasnya sesuai dengan nilai atau nominal yang dikeluarkan untuk mendapatkan layanan jasa atau produk tersebut. Bila suatu produk membuat konsumen 
mengeluarkan biaya yang lebih besar dari manfaat yang diterima, maka yang terjadi adalah suatu produk atau jasa tersebut akan dinilai negatif. Konsumen mungkin akan kecewa dan tidak akan kembali membeli atau menggunakan produk dan jasa perusahaan.

Berikut ada empat pendekatan dalam penetapan harga, diantaranya adalah sebagai berikut :

1) Strategi harga premium, dimana perusahaan menghasilkan produk atau jasa dengan kualitas dan mutu yang tinggi disesuaikan dengan harga yang tinggi.

2) Strategi ekonomi, dimana perusahaan menghasilkan produk atau jasa berkualitas rendah dan disesuaikan dengan harga yang rendah.

3) Strategi nilai baik, dimana perusahaan menghasilkan produk atau jasa berkualitas baik namun dengan harga yang relatif rendah.

4) Strategi penetapan harga tinggi, dimana perusahaan menetapkan harga produk atau jasa yang tinggi namun untuk jangka panjang produk tersebut akan ditinggalkan oleh konsumen karena keluhan terhadap produk tersebut.

\section{Digital Marketing}

Menurut (Chakti, 2014) digital marketing atau yang biasa disebut pemasaran digital merupakan segala upaya pemasaran yang dilakukan menggunakan perangkat yang terhubung dengan internet. Pemasaran digital dilakukan dengan beragam strategi dan media digital bertujuan melakukan komunikasi kepada calon konsumen melalui saluran komunikasi online. Berbagai akses digital marketing yang memudahkan pemasaran diantaranya website, blog, media sosial (facebook, instagram), interactive audio video (youtube, video), interactive audio (podcast, soundcloud, spotify), display ads dan market place (shopee, bukalapak, tokopedia, traveloka, pegi-pegi). Berbagai aspek yang perlu diperhatikan dalam memaksimalkan digital marketing yaitu kemudahan konsumen dalam mengakses, kecepatan dan ketepatan informasi, visualisasi produk yang menarik dan keamanan dalam bertransaksi.

Berikut penjelasan mengenai saluran media digital (digital media channels) yaitu teknik komunikasi online yang digunakan dengan tujuan untuk mencapai kesadaran merek, keakraban dan mempengaruhi niat konsumen untuk membeli dengan mendorong pengguna media digital untuk mengunjungi situs untuk terlibat dengan merek atau produk jasa sehingga memiliki ketertarikan untuk membeli produk atau jasa secara online. Adapun enam saluran utama media digital (digital media channels) diantaranya :

1) Search Engine Marketing (SEM)

Penggunaan iklan online pada halaman search engineatau mesin pencari untuk membantu pengunjung menemukan website produk pemasar dengan menempatkan pesan di mesin pencari untuk mendorong klik-tayang ke situs web ketika konsumen mengetikkan frase kata kunci tertentu. Terdapat dua cara dalam saluran Search Engine Marketing (SEM) yaitu penempatan berbayar atau tautan bersponsor menggunakan sistem pay-per-clic (PPC) dan penempatan dalam daftar utama dengan pengoptimalan mesin pencari atau search engine optimation(SEO).

2) Online $P R$

Mengoptimalkan interaksi yang menguntungkan merek, produk atau situs web perusahaan menggunakan situs pihak ketiga seperti jejaring sosial atau blog yang secara kebetulan dikunjungi oleh target audiens perusahaan.

3) Online partnership

Membentuk dan mengatur pengaturan jangka panjang dalam mempromosikan layanan online suatu perusahaan di situs web pihak ketiga atau melalui komunikasi 
email. Kerjasama lainnya yaitu dalam hal membangun tautan, pemasaran afiliasi, agregat seperti situs sponsor online, perbandingan harga dan co-branding.

4) Interactive advertising

Iklan online berupa spanduk (banner) dan iklan multimedia untuk mencapai kesadaran merek dan mendorong konsumen untuk melakukan clickthrough ke situs pemasar.

5) Opt-in email marketing

Penggunaan daftar internal untuk melakukan komunikasi, aktivasi dan mempertahankan pelanggan. Cara ini dilakukan dengan menambah daftar kontak dalam email marketing, sehingga pelanggan yang telah melakukan regristrasi dan menyetujui aktivasi akan mendapatkan email rutin seputar paket promosi produk atau jasa perusahaan.

6) Social media marketing

Media sosial merupakan media yang didesain untuk memudahkan interaksi sosial secara dua arah. Media sosial menjadi kategori yang penting dalam pemasaran digital. Dalam hal ini, pemasaran digital mendorong dan melibatkan komunikasi pelanggan di situs perusahaan menggunakan facebook, twitter, instagram, dan situs media sosial lainnya. Perusahaan dapat memposting informasi mengenai produk atau jasa secara rutin agar dapat diterima oleh konsumen. Media sosial saat ini memiliki kekuatan yang cukup besar bagi kegiatan pemasaran, karena penyebaran informasi di media sosial cukup cepat dan strategis. Memungkinkan suatu hal menjadi viral, terkenal dan diminati masyarakat.

\section{Peneliti Terdahulu}

(Gulla et al., 2015) meneliti tentang analisis harga, promosi dan kualitas pelayanan terhadap kepuasan konsumen pada hotel Manado Grand Inn. Hasil dari penelitiannya memberikan kesimpulan jika harga, promosi dan kualitas pelayanan secara umum berpengaruh signifikan terhadap kepuasan konsumen pada Hotel Manado Grace Inn.

(Suryadharma \& Nurcahya, 2015) meneliti tentang pengaruh kualitas pelayanan pada kepuasan konsumen hotel Bintang Pesna di Denpasar Timur. Hasil dari penelitian ini memberikan kesimpulan jika variabel kualitas pelayanan yang terdiri atas lima dimensi yaitu bukti fisik, kehandalan, daya tanggap, keamanan dan kepedulian secara simultan memberikan pengaruh pada kepuasan konsumen di Hotel Bintang Pesona yang berlokasi di Denpasar Timur.

(Atmaja \& Ruliana, 2017) meneliti tentang strategi promosi hotel melalui wisata syariah dalam mningkatkan kualitas pelayanan jasa. Hasil dari penelitian ini menyimpulkan bahwa, strategi promosi melalui wisata dapat meningkatkan kualitas pelayanan jasa yang diberikan oleh manajemen Sari Ater Hotel \& Resort.

(Adeline Wijaya, 2017) meneliti tentang bauran pemasaran yang mempengaruhi loyalitas konsumen di Garden Palace. Berdasarkan penelitian tersebut, dapat disimpulkan jika secara kesesluruhan bauran pemasaran berpengaruh positif dan signifikan terhadap kepuasan konsumen. Sedangkan kepuasan konsumen memiliki pengaruh positif terhadap loyalitas konsumen di hotel Garden Palace.

\section{Pengembangan Hipotesis}

Menurut(Anshori, 2020), hipotesis merupakan suatu korelasi variabel-variabel terhadap pokok masalah yang ada dan merupakan jawaban sementara atas suatu masalah. 1) Ada pengaruh signifikan kualitas pelayanan terhadap loyalitas konsumen di Grand 
Wahid Hotel Salatiga.

2) Ada pengaruh signifikan lokasi usaha terhadap loyalitas konsumen di Grand Wahid Hotel Salatiga.

3) Ada pengaruh signifikan harga terhadap loyalitas konsumen di Grand Wahid Hotel Salatiga.

4) Ada pengaruh signifikan digital marketing terhadap loyalitas konsumen di Grand Wahid Hotel Salatiga.

5) Ada pengaruh signifikan pengaruh kualitas pelayanan, lokasi, harga dan digital marketing secara simultan terhadap loyalitas konsumen di Grand Wahid Hotel Salatiga.

\section{MODEL PENELITIAN}

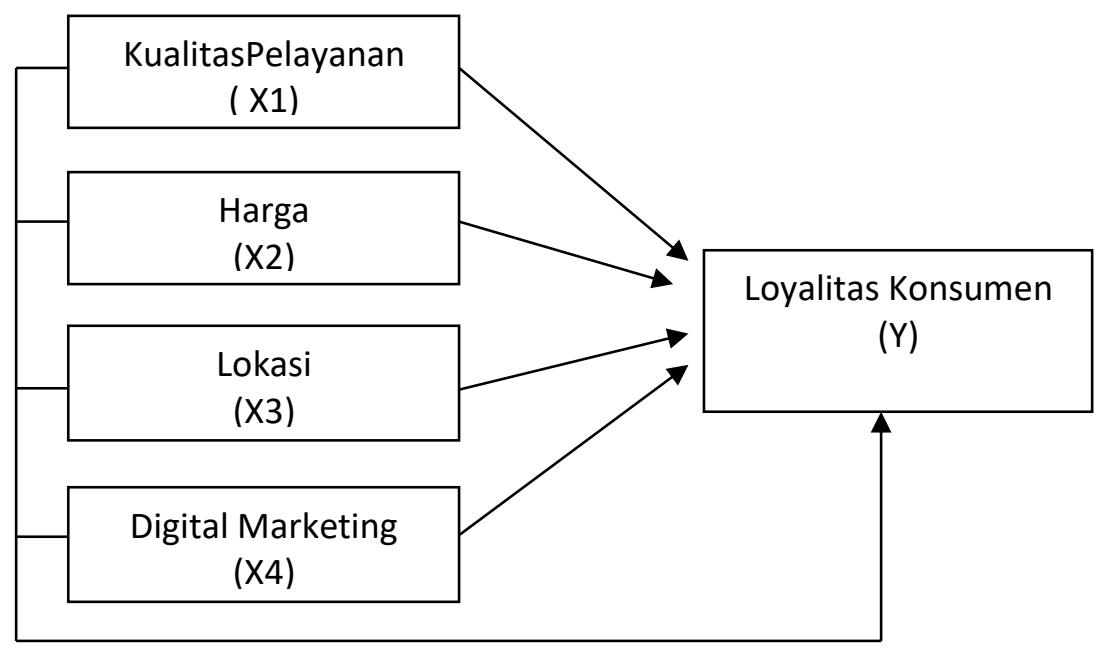

Gambar 1 Model Penelitian

\section{METODE PENELITIAN}

Metode penelitian adalah strategi umum yang dianut dalam pengumpulan dan analisis data yang diperlukan guna menjawab persoalan yang dihadapi. Sedangkan dalam buku Metode Penelitian Kualitatif (Unaradjan, 2019) menerangkan bahwa metode penelitian merupakan satu teknik atau cara yang digunakan dalam suatu penelitian. Metode penelitian dapat berbentuk survey, eksperimen, naturalistik, ex post facto, policy research, action reserch, evaluasi dan sejarah. Tipe penelitian yang di gunakan dalam penelitian ini adalah penelitian eksplanatori, yaitu penelitian yang berusaha menguji hipotesis yang menyatakan pengaruh dua variabel atau lebih. Dalam penelitian ini untuk mengetahui pengaruh kualitas pelayanan, lokasi, harga dan digital marketing terhadap loyalitas konsumen Grand Wahid Hotel Salatiga.

Berdasarkan pengertian di atas, maka metode penelitian adalah cara kerja yang digunakan peneliti dalam usaha mencari, mengumpulkan, mengelola data dan memformulasikan dalam bentuk laporan atau tulisan ilmiah.

\section{Populasi dan Sampel}

Menurut Buku Pengantar Statistik Kesehatan (Chandra, 1995) Populasi atau yang disebut universe adalah sekelompok individu atau obyek yang berkarakter sama, seperti 
sekelompok individu di masyarakat yang mempunyai umur, jenis kelamin, pekerjaan, status sosial atau obyek lain yang mempunyai karakteristik sama. Populasi dalam penelitian ini adalah rata-rata konsumen Grand Wahid Hotel Salatiga selama bulan Januari - Agustus 2020 yang berjumlah 3090 orang.

Menurut Buku Pengantar Statistik Kesehatan (Chandra, 1995)Sampel adalah sebagian dari wakil populasi yang ingin diteliti yang ciri-ciri dan keberadaan populasi mewakili yang sebenarnya dan memiliki karakteristik sama. Untuk menentukan berapa jumlah sampel yang akan di ambil dalam penelitian ini, peneliti mengenakan rumus Slovin tersebut dapat di tulis sebagai berikut : Dalam penelitian ini untuk menentukan jumlah responden sebanyak 97 orang tersebut peneliti menggunakan teknik Judgment Sampling yaitu teknik penentetuan sample dari anggota populasi yang dipilih sekehendak hati peneliti (Suprano dan Sugiarto, 2003:163 ). Alasan menggunakan teknik tersebut karena peneliti sangat benar-benar tau dan siapa saja yang layak untuk di pilih menjadi responden dalam penelitian ini.

\section{Jenis dan Sumber Data}

1) Data Primer : Menurut Hanke \& Reitch tahun 1998 dalam (Yulianto et al., 2018) data primer merupakan data yang diperoleh secara langsung dengan survey lapangan dan menggunakan semua metode pengumpulan data original. Dalam peneliti ini sumber data primer di peroleh dengan melakukan pebagian kuisoner penelitian kepada 97 orang responden.

2) Data Sekunder : Menurut Hanke \& Reitch tahun 1998 dalam (Yulianto et al., 2018) data sekunder merupakan data yang telah dikumpulkan oleh lembaga pengumpul data dan sudah dipublikasikan kepada masyarakat dan pengguna jasa sehingga dapat langsung digunakan. Sumber data dalam penelitian ini diperoleh dari bukubuku penunjang penelitian dan data yang telah tersedia sebelum nya data di gunakan dari jurnal dan publikasi dari internet.

\section{Metode Pengumpulan Data}

1) Observasi adalah pengumpulan data yang dilakukan dengan mengamati langsung kondisi objek penelitian khusus nya di dalam penelitian ini penulis melakukan observasi di Grand Wahid Hotel Salatiga

2) Metode Wawancara adalah pengumpulan data yang di lakukan dengan cara mengajukan sejumlah pertanyaan kepada responden atau narasumber berkaitan dengan penelitian ini.

3) Kuisioner adalah pengumpulan data dengan cara menyebarkan angket-angket yang nanti di isi oleh responden yaitu konsumen Grand Wahid Hotel Salatiga. Pertanyaan dalam kuisoner yang di tuangkan dalam ukuran skala likert yang digunakan dalam penelitian ini meliputi:

$\begin{array}{ll}\text { Sangat Setuju } & \text { : di beri skor } 4 \\ \text { Setuju } & : \text { di beri skor } 3 \\ \text { Tidak Setuju } & : \text { di beri skor } 2 \\ \text { Sangat Tidak Setuju } & \text { : di beri skor } 1\end{array}$




\section{Metode Analisis Data}

\section{Uji Validitas dan Reliabilitas}

Validitas adalah suatu ukuran yang menunjukan tingkat-tingkat kevalidan kesahihan suatu kesasihan suatu intrumen. Suatu istrumen yang valid atau sahih mempunyai validitas tinggi. Sebaliknya Sebaliknya, instrumen yang kurang valid berarti memiliki validitas rendah" (Suharsimi, 2006: 168). Dalam penelitian ini menggunakan taraf signifikan 0,05 ang merupakan ukuran standar yang sering di gunakan untuk penelitian. Untuk mengetahui $\mathrm{r}$ tabel digunakan rumus $\mathrm{df}=\mathrm{n}-2$, dimana $\mathrm{n}$ adalah jumlah sample dengan degree of freedom sebesar $5 \%$ atau a/2 pada tabel.

Reliabilitas menunjuk pada suatu pengertian bahwa sesuatu instrument cukup dapat dipercaya untuk digunakan sebagai alat pengumpul data karena instrument tersebut sudah baik. Menurut Nunnally dalam Ghozali (2011:48) "reliabilitas instrument dari penelitian ini dihitung dengan bantuan komputer SPSS menggunakan uji statistic Cronbach Alpha, untuk mengetahui apakah data penelitian ini reliable atau tidak. Suatu konstruk atau variable dikatakan reliable jika memberikan nilai CronbachAlpha>0,60".

\section{Analisis Regresi Linier Berganda}

Analisis regresi berganda digunakan untuk mengetahui pengaruhdua variabel bebas atau lebih terhadap satu variabel terkait (Ghazali,2011). Oleh itu analisis regresi linier berganda dapat digunakan untuk menguji hipotesis penelitian ini untuk menguji ada tidak nya pengaruh kualitas pelayanan (X1), lokasi (X2), harga (X3) dan digital marketing (X4) terhadap loyalitas konsumen (Y).

\section{Uji t}

Uji t digunakan unuk menguji kebenaran pernyataan hipotesis I,II, III dan IV penelitian. Berikut prosedur uji statistiknya (Hasan, iqbal 2004:108) adalah sebagai berikut :

Menentukan formulasi hipotesis

a. Ho: $\mathrm{b} 1=\mathrm{b} 2=\mathrm{b} 3=\mathrm{b} 4=0$, berarti tidak terdapat pengaruh kualitas pelayanan (X1), lokasi (X2), harga (X3) dan digital marketing (X4) terhadap loyalitas konsumen (Y).

b. $\mathrm{Ha}: \mathrm{b} 1 \neq \mathrm{b} 2 \neq \mathrm{b} 3 \neq \mathrm{b} 4 \neq 0$, berarti terdapat pengaruh kualitas pelayanan (X1), lokasi (X2), harga (X3) dan digital marketing (X4) terhadap loyalitas kinerja (Y) secara parsial (Individu).

\section{Uji F}

Uji F digunakan untuk menunjukan apakah semua variabel bebas (Independen) yan dimasukan dalam model mempunyai pengaruh secara bersama-sama terhadap variael terikat (dependen). Kualitas pelayanan (X1), lokasi (X2), harga (X3) dan digital marketing (X4), secara simultan terhadap loyalitas konsumen (Y).

\section{Koefisien determinasi}

Menurut Ghozali (2012:97) koefisien determinasi $\left(\mathrm{R}^{2}\right)$ merupakan alat untuk mengukur seberapa jauh kemampuan model dalam menerangkan variasi variabel dependen. Nilai koefisien determinasi adalah antara nol atau satu. Nilai $\mathrm{R}^{2}$ yang kecl 
berarti kemampuan variabel-variabel independen dalam menjelaskan variasi variabel dependen amat terbatas

\section{HASIL DAN PEMBAHASAN}

\section{Hasil Uji Validitas dan Reliabilitas}

Dari hasil uji validitas bahwa dari kelima variabel yang terdiri dari 22 butir pertanyaan, hasil yag didapatkan semuanya dinyatakan valid karena $r$ hitung lebih besar dari $r$ tabel. Sehingga pernyataan dalam kuisioner layak dan bisa digunakan dalam penelitian selanjutnya. Sedangkan, dari hasil uji reliabilitas bahwa dari kelima variabel yang terdiri dari 5 indikator, dinyatakan reliabel karena Cronbach Alpha lebih besar dari Alpha pembanding. Maka dari itu bisa digunakan pada penelitian selanjutnya.

\section{Hasil Analisis Regresi Linier Berganda}

Berdasarkan hasil analisis regresi linier berganda tersebut diperoleh data sebagai berikut :

Berdasarkan pada hasil analisis regresi linier berganda, dapat di jelaskan persamaan regresi linier berganda sebagai berikut :

$$
\mathrm{Y}=1,581+0,155 \mathrm{X} 1+0,076 \mathrm{X} 2+0,253 \mathrm{X} 3+0,345 \mathrm{X} 4
$$

Dari persamaan di atas maka secara umum dapat di interprestasikan penjelasan sebagai berikut :

1) Konstanta (a) = 1,581 artinya jika variable kualitas pelayanan (X1), lokasi (X2), harga (X3) dan digital marketing $(\mathrm{X} 4)=0$ maka besarnya variabel loyalitas konsumen adalah sebesar 1,581 satuan.

2) Koefisien regresi variabel kualitas pelayanan (b1) $=0,155$ artinya setiap peningkatan kualitas pelayanan sebesar satu satuan akan meningkatkan loyalitas konsumen sebesar 0,155 satuan dengan asumsi variabel lainnya di anggap tetap atau ceteris paribus.

3) Koefisien regresi variabel lokasi $(\mathrm{b} 2)=0,076$ artinya setiap peningkatan lokasi sebesar satu satuan akan meningkatkan loyalitas konsumen sebesar 0,076 satu satuan dengan asumsi variabel lainnya dianggap ceteris paribus.

4) Koefisien regresi variabel harga $(\mathrm{b} 3)=0,253$ artinya setiap peningkatan harga sebesar satu satuan akan meningkatkan loyalitas konsumen sebesar 0,253 satu satuan dengan asumsi variabel lainnya dianggap ceteris paribus.

5) Koefisien regresi variabel digital marketing (b4) $=0,345$ artinya setiap peningkatan digital marketing sebesar satu satuan akan meningkatkan loyalitas konsumen sebesar 0,345 satu satuan dengan asumsi variabel lainnya dianggap ceteris paribus.

\section{Hasil Uji t}

1) Pengujian Hipotesis 1 Penelitian

Pengujian hipotesis 1 penelitian yang menyatakan "Terdapat pengaruh signifikan kualitas pelayanan terhadap loyalitas konsumen di Grand Wahid Hotel Salatiga" Dari hasil analisis data dengan SPSS 18 diperoleh nilai t hitung sebesar 1,835 sedangkan nilai $\mathrm{t}$ table pada taraf signifikan 5\%/2 dan df $(n-k-1=97-4-1=92)=t(0,025 ; 92)$ adalah sebesar 1,98609 yang berarti pernyataan hipotesis 1 penelitian "Terdapat pengaruh signifikan kualitas pelayanan terhadap loyalitas konsumen di Grand Wahid Hotel Salatiga 
di tolak. Hal ini ditunjukkan dengan $\mathrm{t}$ hitung $<\mathrm{t}$ tabel yaitu $1,835<1,98609$. Artinya jika kualitas pelayanan ditingkatkan maka tidak berpengaruh pada loyalitas konsumen.

2) Pengujian Hipotesis 2 Penelitian

Pengujian hipotesis 2 penelitian yang menyatakan "Terdapat pengaruh signifikan lokasi terhadap loyalitas konsumen di Grand Wahid Hotel Salatiga". Dari hasil analisis data dengan SPSS 18 diperoleh nilai t hitung sebesar 0,883 sedangkan nilai t table pada taraf signifikan 5\%/2 dan df $(n-k-1=97-4-1=92)=t(0,025 ; 92)$ adalah sebesar 1,98609 yang brarti pernyataan hipotesis 2 penelitian "Terdapat Pengaruh signifikan lokasi terhadap loyalitas konsumen di Grand Wahid Hotel Salatiga di tolak. Artinya jika lokasi ditingkatkan maka tidak berpengaruh signifikan pada loyalitas konsumen.

3) Pengujian Hipotesis 3 Penelitian

Pengujian hipotesis 3 penelitian yang menyatakan "Terdapat pengaruh signifikan harga terhadap loyalitas konsumen di Grand Wahid Hotel Salatiga" dari hasil analisis data dengan SPSS 18 diperoleh nilai t hitung sebesar 2,312 sedangkan nilai t table pada taraf signifikan 5\%/2 dan df $(n-k-1=97-4-1=92)=\mathrm{t}(0,025 ; 92)$ adalah sebesar 1,98609. Dapat disimpulkan $r$ hitung $>r$ tabel yaitu 2,312 < 1,98609 yang brarti pernyataan hipotesis 3 penelitian "Terdapat Pengaruh signifikan harga terhadap loyalitas konsumen Grand Wahid Hotel Salatiga dapat diterima. Artinya jika hargaditingkatkan maka loyalitas konsumen akan meningkat pula.

4) Pengujian Hipotesis IV Penelitian

Pengujian hipotesis IV penelitian yang menyatakan "Terdapat pengaruh signifikan digital marketing terhadap loyalitas konsumen di Grand Wahid Hotel Salatiga" dari hasil analisis data dengan SPSS 18 diperoleh nilai t hitung sebesar 3,379 sedangkan nilai t table pada taraf signifikan 5\%/2 dan df $(\mathrm{n}-\mathrm{k}-1=97-4-1=92)=\mathrm{t}(0,025 ; 92)$ adalah sebesar 1,988. Dapat disimpulkan t hitung > t tabel yaitu 3,379>1,98609 yang brarti pernyataan hipotesis IV penelitian "Terdapat Pengaruh signifikan digital marketing terhadap loyalitas konsumen di Grand Wahid Hotel Salatiga dapat diterima. Artinya jika digital marketingditingkatkan maka loyalitas konsumen juga akan meningkat pula.

\section{Uji F Pengujian Hipotesis V Penelitian}

Pengujian hipotesis V penelitian yang menyatakan "Terdapat pengaruh signifikan kualitas pelayanan, lokasi, harga dan digital marketing secara simultan terhadap loyalitas konsumen di Grand Wahid Hotel Salatiga" hasil uji F dapat dijelaskan bahwa nilai F hitung berada di daerah penerimaan $\mathrm{Ha}$, sehingga pernyataan hipotesis $\mathrm{V}$ penelitian. Terdapat pengaruh signifikan kualitas pelayanan, lokasi, harga dan digital marketing secara simultan terhadap loyalitas konsumen di Grand Wahid Hotel Salatiga. Dapat diterima, artinya jika kualitas pelayanan, lokasi, harga dan digital marketing ditingkatkan maka loyalitas konsumen akan meningkat.

\section{Hasil Uji Koefisien Determinasi}

Koefisien Determinasi digunakan untuk mengetahui besarnya sumbangan variabel independen kualitas pelayan (X1), lokasi (X2), harga (X3) dan digital marketing terhadap variabel dependen loyalitas konsumen (Y). Berdasarkan hasil analisis regresi diperoleh nilai koefisien determinasi Adjusted R Square sebesar 0,416 atau 41,6\%. Nilai tersebut menunjukan bahwa variabel dependen yaitu variabel loyalitas konsumen 41,6 \% dapat dijelaskan oleh variabel independen dalam hal ini kualitas pelayanan (X1), lokasi (X2), harga (X3) dan digital marketing (X4). Sedangkan sisanya 58,4\% dijelaskan oleh variabel lainnya yang tidak diteliti misalkan persaingan, citra merek, kebijakan 
pemerintah, karakteristik perusahaan, kolaborasi mitra bisnis, inovasi dan lain sebagainya.

\section{PENUTUP}

Berdasarkan hasil analisis penelitian dan pembahasan mengenai kualitas pelayanan, lokasi, harga dan digital marketing terhadap loyalitas konsumen di Grand Wahid Hotel Salatiga, maka dapat ditarik beberapa kesimpulan

1) Tidak ada pengaruh signifikan kualitas pelayanan terhadap loyalitas konsumen di Grand Wahid Hotel Salatiga

2) Tidak terdapat Pengaruh signifikan lokasi terhadap loyalitas konsumen di Grand Wahid Hotel Salatiga

3) Terdapat Pengaruh signifikan harga terhadap loyalitas konsumen Grand Wahid Hotel Salatiga

4) Terdapat pengaruh signifikan digital marketing terhadap loyalitas konsumen di Grand Wahid Hotel Salatiga

5) Terdapat pengaruh signifikan kualitas pelayanan, lokasi, harga dan digital marketing secara simultan terhadap loyalitas konsumen di Grand Wahid Hotel Salatiga

Berdasarkan uraian tentang pembahasan dan kesimpulan diatas, peneliti dapat mengungkapkan beberapa saran antara lain

1) kualitas pelayanan di Grand Wahid Hotel Salatiga dinilai sudah baik, namun Grand Wahid Hotel Salatiga harus terus meningkatkan kualitas pelayanan agar loyalitas konsumen dapat meningkat dan Grand Wahid Hotel Salatiga dapat mempertahankan dan menaikan occupancy hotel.

2) Grand Wahid hotel Salatiga perlu meningkatkan lokasi dan kenyamanan bagi pengunjung. Terutama kenyamanan dalam hal lokasi parkir. Untuk letak Grand Wahid Hotel Salatiga sudah cukup strategis dan mudah untuk diakses konsumen.

3) Grand Wahid Hotel Salatiga perlu meningkatkan pertimbangan dalam menentukan harga agar mampu bersaing, kompetitif namun tetap dapat diterima dan terjangkau oleh konsumen.

4) Digital Marketing di Grand Wahid Hotel Salatiga sudah baik, namun perlu dikembangkan lagi fitur-fitur lain agar konsumen bisa secara langsung memesan melalui website. Selain itu, dengan design promosi yang unik melalui digital marketing maka konsumen akan lebih tertarik. Loyalitas konsumen terhadap Grand Wahid Hotel Salatiga akan meningkat jika Grand Wahid Hotel Salatiga terus meningkatkan kualitas pelayanan, lokasi, harga dan digital marketing secara konsisten.

5) Saran bagi penelitian selanjutnya adalah sebaiknya penelitian berkembang ke variabel lain yang mempengaruhi keputusan pembelian seperti faktor citra merk, faktor persaingan, kebijakan pemerintah, karakteristik perusahaan, kolaborasi mitra bisnis, inovasi dan lain sebagainya.

\section{DAFTAR PUSTAKA}

Adeline Wijaya, C. (2017). Bauran pemasaran yang mempengaruhi loyalitas konsumen di Garden Palace. Jurnal Hospitality Dan Manajemen Jasa, 5, 264-277.

Afrilia, \& Ascharisa Mettasatya. (2018). Digital marketing sebagai strategi komunikasi 
pemasaran "Waroenk Ora Umum" dalam meningkatkan jumlah konsumen. Jurnal Riset Komunikasi, 1, 147-157.

Aji, R. (2016). Digitalisasi, era tantangan media (Analisis kritis kesiapan fakultas dakwah dan komunikasi menyongsong komunikasi di era digital). Islamic Communication Journal, 01, 43-54.

Anshori, M. (2020). Metodologi Penelitan Kuantitatif Edisi 2 (2nd ed.). Airlangga University Press.

Atmaja, S., \& Ruliana, P. (2017). Strategi promosi hotel melalui wisata syariah dalam meningkatkan kualitas pelayanan jasa. Jurnal Komunikasi, 2, 182-191.

Atmajati, A. (2018). Layanan prima dalam praktik saat ini (R. Kozara \& I. F. Iriyanto (eds.); 1st ed.). deepublis publisher.

Barata, A. A. (2003). Dasar-dasar pelayanan prima (R. L. Toruan (ed.)). PT. Elex Media Komputindo.

Chakti, G. A. (2014). The Book of Digital Marketing (Sobirin (ed.); 1st ed.). Makasar, Penerbit Celebes Media Perkasa.

Chakti, G. A. (2019). The book of digital marketing (Sobirin (ed.); 1st ed.). Makasar, Celebes Media Perkasa.

Chandra, B. (1995). Pengantar statistik kesehatan (1st ed.). Penerbit buku kedokteran EGC.

Devi, E. (2018). Pengantar akomodasi dan restoran (1st ed.). deepublis publisher.

Emmywati. (2016). Pengaruh kualitas layanan yang terdiri dari kenyamanan, keamanan, kemudahan dan fasilitas terhadap kepuasan konsumen pada galeri seni dan pusat meditation Ponorogo Jawa Timur. Jurnal Penelitian Ilmu Managemen, 1, 184-191.

Fathoni, A. (2016). Analisa faktor-faktor yang mempengaruhi pemilihan lokasi terhadap tingkat penjualan usaha jasa mikro di Kabupaten Lamongan. Jurnal Penelitian Ilmu Managemen, 1, 22-33.

Firmansyah, A. (2019). Pemasaran: Dasar dan Konsep. Penerbit Qiara Media.

Gulla, R., Oroh, S. G., \& Roring, F. (2015). Analisis harga, promosi dan kualitas pelayanan terhadap kepuasan pada hotel Manado Grace Inn. Jurnal EMBA, 3, 1313-1322.

Hartono, H., Hutomo, K., \& Mayangsari, M. (2012). Pengaruh strategi pemasaran terhadap peningkatan penjualan pada perusahaan dengan menetapkan alumni dan mahasiswa Universitas Bina Nusantara sebgai objek penelitian. Binus Business Review, 3, 882-897.

Indahingwati, A. (2019). Kepuasan Konsumen Pada Kualitas Layanan SIM Keliling (F. Rahmawati (ed.)). Jakad Publishing.

Jos, D. P. (2004). Teori Semantik. Erlangga.

Moeljiono, D. (2004). Budaya korporat dan keunggulan korporasi (1st ed.). PT. Elex Media Komputindo.

Nurulaili, \& Wijayanto, A. (2013). Analisis faktor-faktor yang memengaruhi loyalitas 
konsumen tupperware. Jurnal Administrasi Bisnis, 2, 89-97.

Putri, Y. L. (2017). Pengaruh kualitas pelayanan terhadap loyalitas pelanggan dengan kepuasan sebagai variabel intervening (Studi persepsi pada pelanggan Dian Comp AMbarawa). Among Makarti, 10, 70-90.

Riyono, \& Budiharja, G. E. (2016a). Pengaruh kualitas produk, harga, promosi dan bran image terhadap keputusan pembelian produk aqua di Kota Pati. Jurnal STIE Semarang, 8, 92-121.

Riyono, \& Budiharja, G. E. (2016b). Pengaruh kualitas produk, harga, promosi dan brand image terhadap keputusan pembelian produk Aqua di Kota Pati. Jurnal STIE Semarang, 8, 92-121.

Sanaubar, G., Hidayat, W., \& Kusuma, H. (2017). Pengaruh potensi pariwisata terhadap penyerapan tenaga kerja sektor perhotelan di 9 Kabupaten/Kota Provinsi Jawa Timur Tahun 2012-2015. Jurnal Ilmu Ekonomi, 1, 324-339.

Setiawan, S. (2011). Loyalitas Pelanggan Jasa (P. Komalasari (ed.); 1st ed.). PT Penerbit IPB Press.

Shinta, A. (2011). Manajemen Pemasaran (A. Manshur (ed.)). Universitas Brawijaya Malang Press.

Sibarani, C. G. G. T., Armayanti, N., Irwansyah, \& Suharianto, J. (2019). Dasar-dasar kewirausahaan (J. Simarmata (ed.); 1st ed.). Yayasan kita menulis.

Sidiq, R. (2019). Teknik Berjualan Dengan Digital Marketing. UDACODING.

Sudarsono, H. (2020). Buku Ajar : Manajemen Pemasaran (1st ed.). CV Pustaka Abadi.

Suprapto, R., \& Azizi, Z. W. (2020). Buku Ajar Manajemen Pemasaran (Tama (ed.); 1st ed.). Myria Publisher.

Suryadharma, I. W. W., \& Nurcahya, I. K. (2015). Pengaruh kualitas pelayanan pada kepuasan pelanggan hotel Bintang Pesona di Denpasar Timur. E-Jurnal Manajemen Unud, 4, 930-942.

Tjiptono, F. (2000). Perspektif Manajemen \& Pemasaran Kontemporer (1st ed.). Penerbit Andi Yogyakarta.

Tjiptono, F. (2014a). Pemasaran Jasa - Prinsip, Penerapan, dan Penelitian (1st ed.). Penerbit Andi Yogyakarta.

Tjiptono, F. (2014b). Pemasaran Jasa - Prinsip, Penerapan dan Penelitian (1st ed.). Penerbit Andi Yogyakarta.

Umar, H. (2005). Riset Pemasaran dan Perilaku Konsumen (4th ed.). PT. Gramedia Pustaka Utama.

Unaradjan, D. D. (2019). Metode Penelitian Kuantitatif (K. Sihotang (ed.); 1st ed.). Penerbit Universitas Katolik Indonesia Atma Jaya.

Warnadi, \& Triyono, A. (2019). Manajemen Pemasaran (I. Astarina \& H. Ramadhani (eds.); 1st ed.). Penerbit Deepublish.

Wibowo, D. H., Arifin, Z., \& Sunarti. (2015). Analisis strategi pemasaran untuk meningkatkan daya saing UMKM (Studi pada batik Diajeng Solo). Jurnal 
Jurnal Among Makarti Vol. 14 No. 1 - Tahun 2021 I 108

Administrasi Bisnis, $\quad 1, \quad$ 59-66. https://doi.org/administrasibisnis.studentjournal.ub.ac.id

Yulianto, N. A. B., Maskan, M., \& Utaminingsih, A. (2018). Metodeologi Penelitian Bisnis (H. N. Utami (ed.); 1st ed.). Polinema Press.

Yuliawati, Y. (2016). Pengaruh motivasi dan sikap terhadap loyalitas konsumen pada studio Jonas Photo. Jurnal Pendidikan Manajemen Bisnis, 11, 11-14. 